\title{
Functional health literacy and healthy eating: Understanding the brazilian food guide recommendations
}

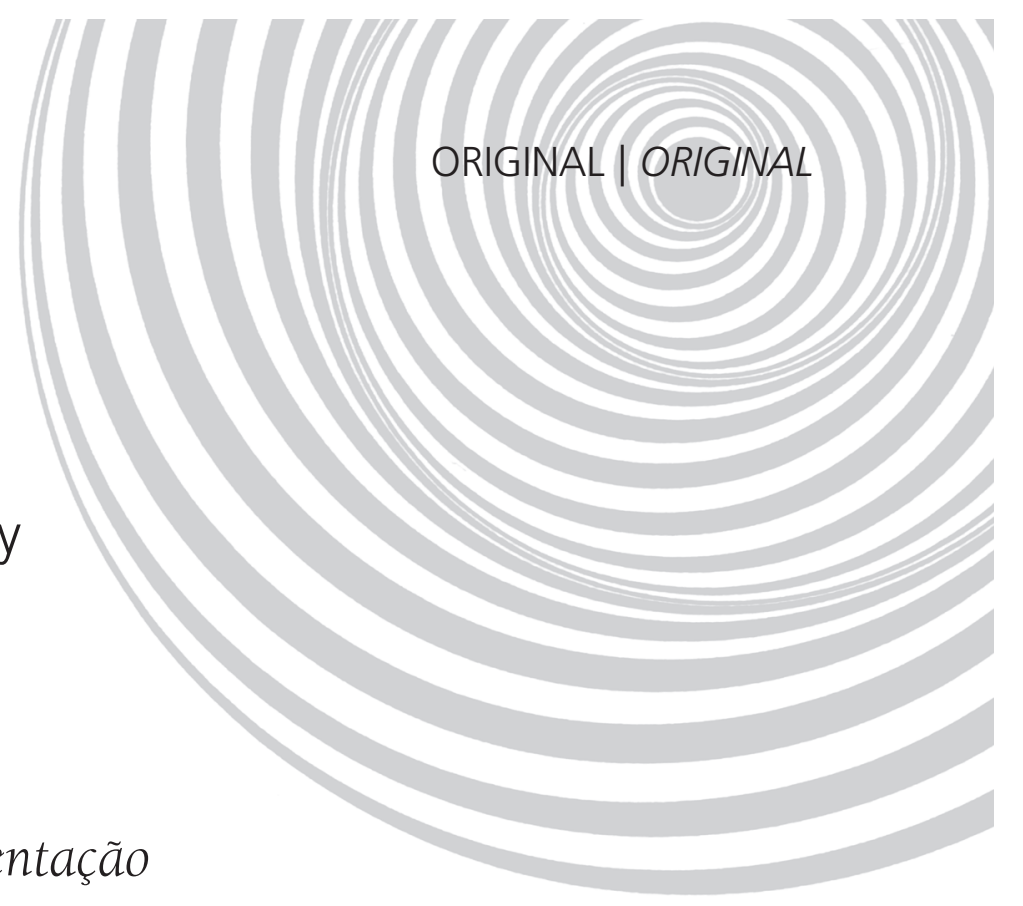

\section{Letramento funcional em saúde e alimentação \\ saudável: compreensão de recomendações \\ do guia alimentar brasileiro}

Maria Auristela Magalhães COELHO ${ }^{1}$

Helena Alves de Carvalho SAMPAIO ${ }^{1}$

Maria da Penha Baião PASSAMAI ${ }^{2}$

Lissidna Almeida CABRAL ${ }^{1}$

Tatiana Uchôa PASSOS²

Gláucia Posso LIMA'

A B S T R A C T

\section{Objective}

To assess the relationship between the functional health literacy of Unified Heath System users and the understanding of food servings in the pocket version of the Brazilian Food Guide.

\section{Methods}

Functional health literacy was assessed by the Brief Test of functional health literacy. Two dialogue rounds were conducted with patients with adequate functional health literacy (Group 1) and inadequate functional health literacy (Group 2). The dialogues were recorded and analyzed according to the discourse of the collective subject.

\section{Results}

Most (58.0\%) users had inadequate functional health literacy. Five core areas were identified: understands serving sizes; does not understand serving sizes; serving sizes are confusing; unfamiliar/uncommon foods; small letters. Group 2 had more trouble understanding.

${ }^{1}$ Universidade Estadual do Ceará, Faculdade de Medicina, Programa de Pós-Graduação em Saúde Coletiva. Av. Paranjana, 1700, Campus do Itaperi, 60714-903, Fortaleza, CE, Brasil. Correspondência para/Correspondence to: MAM COELHO.

E-mail: <auristela@unifor.br>.

2 Universidade Estadual do Ceará, Centro de Ciências, Curso Ciências Biológicas. Fortaleza, CE, Brasil. 


\section{Conclusion}

Difficulty understanding hinders health promotion. Individuals need to have access to educational materials that are easier to understand and developed taking their functional health literacy into account.

Indexing terms: Food guide. Functional health literacy. Health food.

\section{R E S U M O}

\section{Objetivo}

Avaliar a relação entre o letramento funcional em saúde de usuários do Sistema Único de Saúde e o entendimento das porções alimentares do Guia Alimentar Brasileiro, versão bolso.

\section{Métodos}

Foi avaliado o letramento funcional em saúde com o Brief Test of Functional Health Literacy. Foram realizados dois círculos de diálogos, envolvendo pacientes com letramento adequado (Grupo 1) e insuficiente (Grupo 2). Os diálogos foram gravados e analisados segundo o discurso do sujeito coletivo.

\section{Resultados}

A maioria dos participantes apresentou letramento funcional em saúde insuficiente (58,0\%). Foram identificadas cinco ideias centrais: entende o consumo em porções de alimentos; não entende o consumo em porções de alimentos; porções de alimentos colocadas de forma confusa; alimentos desconhecidos/não comuns; letras pequenas. A compreensão dos integrantes do Grupo 2 foi mais limitada.

\section{Conclusão}

As dificuldades de entendimento representam um fator de dificuldade na promoção da saúde. Há necessidade de empoderar os indivíduos mediante a disponibilidade de materiais educativos de mais fácil compreensão, em conformidade com seu letramento funcional em saúde.

Termos de indexação: Guias alimentares. Letramento funcional em saúde. Alimentos naturais.

\section{N T R O D U C T IO N}

Today health care focuses on disease prevention and consequences, such as disability, chronic suffering, and early death ${ }^{1}$. It is in the scope of this process that health education appears. Health education transcends curative assistance because it prioritizes decisions and awareness of health determinants. Hence, health education methods should go beyond the spread of information and provide interaction, participation, and critical analysis. This process is what leads to health literacy².

Dialogic health education models aim to empower individuals or communities. According to Martínez-Hernáez ${ }^{3}$, education and health promotion should go beyond the practice of the sanitary model, one that privileges sophisticated protocols for investigation-intervention. Health education in this perspective is based on a dialogic relationship that contemplates social participation in health. However, there is a possible obstacle for this process known as Functional Health Literacy (FHL), which has been discussed over decades by American scholars ${ }^{4}$ but has little space in Brazil.

Literacy means the state or condition of the social uses of reading and writing ${ }^{5}$. Meanwhile, FHL is defined as the degree to which individuals can obtain, process, and understand basic information and services necessary for making appropriate health-related decisions ${ }^{6,7}$. Education can improve life conditions in many ways: by improving cognitive ability, helping people to take fewer health-related risks; by improving their learning about the injuries they experience; and by having better access to important information for maintaining good 
health, improving health and physical wellbeing ${ }^{8}$. Appropriate health literacy is therefore a key health determinant ${ }^{9}$. Thus, the entire health education process should take into account the $\mathrm{FHL}$ of the target audience in order to provide actions that effectively empower people and communities.

Many instruments can measure $\mathrm{FHL}$, and the most common are the Rapid Estimate of Adult Literacy in Medicine (REALM) ${ }^{10}$ and the Test of Functional Health Literacy in Adults (TOFHLA)4. However, since this subject has not yet been debated in Brazil, health education actions have not been preceded by a diagnosis of a population's FHL.

An educational instrument developed by the Brazilian Ministry of Health particularly important for the population's health is the pocket version of the Brazilian Food Guide called "Food Guide (GA): How to have a healthy diet"11. This version was made to be distributed to the general public; therefore, it is essential that the target audience can understand the content. The GA is a strategy of the National Policy of Food and Nutrition to ensure Food and Nutrition Security (FNS) from age two years, and to control chronic Noncommunicable Diseases (NCD) ${ }^{12}$. However, in addition to the GA having been created without prior diagnosis of the FHL of its target population, a nationwide strategy to assess the GA has not been designed either. Not even the population's understanding of the food pyramid used by the GA has accessed as an iconic representation of a healthy $\operatorname{diet}^{13}$.

Hence, the objective of this study was to analyze how users of the Sistema Único de Saúde (SUS), Brazilian Unified Health Care System understand daily serving sizes by reading and discussing the pocket version of the Brazilian Food Guide ${ }^{11}$ created by the Ministry of Health How to have a healthy diet, according to their functional health literacy.

\section{METHODS}

This is a descriptive, cross-sectional study with a qualitative and quantitative approach. The research was submitted and approved by the Research Ethics Committee of the Universidade Estadual do Ceará under Protocol $n^{\circ}$ CAAE 0002.0.038.000-09. All participants signed an Informed Consent Form.

The first stage of the study, from August 2010 to March 2011, involved diagnosing the FHL of the participants. A total of 176 individuals who visited the diabetes Mellitus, high blood pressure, and surgery outpatient clinics of a university hospital located in the state capital were interviewed. The patients were selected according to their visit days providing they met the following inclusion criteria: aged 18 to 59 years; literate; and minimum eyesight of 20/50 (Snellen scale) as required by the short version of the Test of Functional Health Literacy in Adults (TOFHLA) ${ }^{4}$. The instrument was used under its authors' consent ${ }^{4}(027 / 10)$.

There are three versions of TOFHLA: the complete version (full-length TOFHLA), the short version (short TOFHLA or S-TOFHLA), and the brief version (Brief Test of Functional Literacy, called in the present study B-TOFHLA). The latter was last translated into Portuguese by Carthery-Goular et al. ${ }^{14}$, who tested the instrument in patients of two public hospitals in $2009^{14}$. The authors considered the instrument appropriate for assessing the FHL of the Brazilian population, and a practical and viable tool for screening functional illiteracy in clinical health settings with individuals who require special $\mathrm{care}^{14}$.

The questionnaire (B-TOFHLA) has fourpoint Likert-type questions totaling 28 points and reading comprehension questions totaling 72 points for a maximum of 100 points. As determined by the instrument, the individuals were categorized as follows: insufficient FHL (scores 0 to 53), marginal FHL (scores 54 to 66), and adequate FHL (scores 67 to 100).

The second stage done from March to May 2011 measured understanding of GA serving 
sizes. The patients were distributed into only two categories: inadequate FHL (insufficient + marginal) and adequate. Ten individuals were chosen for each category to participate in a dialogue round assessing GA serving sizes.

The thirty-two-page GA is divided into three parts and a summary. In the first part, there are 18 questions for users to assess the quality of their diet. The second part presents ten steps for a healthy diet, and teaches how to calculate body mass index and to interpret the result. The third part contains a list of foods divided into groups and respective serving sizes. This third part is complex because it recommends a certain number of servings for each food group, and within the group, each food is shown in the amount that should be consumed, known as one serving. These amounts are presented in cooking units, namely spoons, cups, and units. The complexity in how the data is presented made us discuss it in the second stage of the study.

Eight patients with adequate $\mathrm{FHL}$ and nine patients with inadequate $\mathrm{FHL}$ accepted to participate in this stage, here called Groups 1 and 2 , respectively. The dialogue rounds were performed as proposed by Bohm ${ }^{15}$, in a room of the abovementioned institution's outpatient clinic on a Wednesday (Group 1) and a Friday (Group 2) from 2 p.m. to 4 p.m. The subject was "serving sizes in cooking units." In the first sixty minutes, the content was read and in the second 60 minutes, the group talked about the text they read. All sessions were recorded.

The recordings of the conversations were fully transcribed and analyzed according to the Discourse of the Collective Subject (DCS) proposed by Lefèvre \& Lefèvre $^{16}$. The DCS is a mode of presenting qualitative study results in which the testimonies are used as raw material. The testimonies are summarized and written in the first person singular (I) to express the thought of a group as if this individual had produced the discourse. Key expressions are selected from the most meaningful individual replies. The core ideas of these key expressions are the summary of the discursive content manifested as key expressions.
This material enabled the creation of discourse summaries, the DCS. The software QualiQuantiSoft ${ }^{17}$ was used as a support tool.

Nine core ideas were identified, four (4) in Group 1 and five (5) in Group 2 associated with the GA food groups. Since the objective was to assess understanding of $G A$ serving sizes of different food groups for each core idea, a DCS was constructed for each food group whenever possible. The food groups are: grains (rice, bread, pasta, potato, and cassava); non-starchy vegetables; fruits; legumes (beans); meats (beef, poultry, pork, seafood, and eggs); milk, cheese, and yogurt; oils and fats; and sugars and sweets.

The findings were analyzed and discussed with the meanings/senses represented by the study subjects and its categories interpreted under the light of the pertinent literature.

\section{RES U L T S}

Most participants initially assessed $(n=176)$ were females $(75.6 \%)$. The mean age of the sample was 44.4 years, varying from 19 to 59 years; $41.5 \%$ had finished high school and $33.5 \%$ had not finished elementary school; and $42.0 \%$ had adequate $\mathrm{FHL}, 48.9 \%$ had insufficient $\mathrm{FHL}$, and $9.1 \%$ had marginal FHL. The profile of the patients who accepted to participate in the dialogue rounds matched the entire sample with respect to gender and age; $76.0 \%$ were females and the mean age was 49.9 years (25-59 years), but the education level was a bit higher: $60.0 \%$ had completed high school. Since invitation to participate in the dialogue rounds was random, it is possible that those with more education were more interested in participating.

Among the identified Core Ideas $(\mathrm{Cl})$, four were common to Groups 1 and 2: understands serving sizes within the context $(\mathrm{Cl} 1)$; does not understand serving sizes within the context $(\mathrm{Cl}$ $2)$; serving sizes are confusing $(\mathrm{Cl} 3)$; and foods are unfamiliar/uncommon ( $\mathrm{Cl} 4)$. Additionally, Group 2 had one more core idea: they found the letters too small (CI 5). 
A specific Discourse of the Collective Subject contemplating the food groups was constructed for each core idea. The patients in Group 1 did not mention the dairy products' group (milk, cheese, and yogurt). The other food groups were mentioned, but Group one did not understand them in a satisfactory manner. The only group they understood partially from the qualitative dietary viewpoint was that of grains, but they struggled with serving sizes and the recommended intakes.
All food groups were mentioned by Group 2. However, only the fruits were correctly understood. Although the other groups were mentioned, they were not understood. The presence of unfamiliar/unknown foods is critical because they included grains, non-starchy vegetables, fruits, legumes, and meats (Table 1).

The participants struggled to understand the guide, especially when they were required to deal with numbers.

Table 1. Core Idea $(\mathrm{Cl})$ and discourse of the collective subject refering to serving sizes in cooking units from Unified Health Care System (SUS) patients with inadequate functional health literacy (Group 2). Fortaleza (CE), 2011.

Core Idea
Cl 1
Understands intake in
serving sizes within the
context

Discourse of the collective subject

\section{Fruits}

It says [...] eat three red fruits per day... What do you think, is one enough? Or should you eat all three? Ideally we should follow the instructions in the book, the servings. If it tells us to eat three, we must eat three, but it is hard for us to obey, right? You can eat, for example, a guava in the morning and an apple in the evening, right? Then you will have consumed two. Then you can have a serving of watermelon, right? Then you will have had all three. It should not be the same fruit.

$\mathrm{Cl} 2$ Grains

Does not understand This amount on the side, for example, white rice, four tablespoons, is what we have to eat, right? These four spoons is what we have to consume daily. It is a serving. [...] I'm going to have lunch and then consume this serving. It cannot be more, right? Only the four tablespoons. You can use less and add more leaf vegetables, vegetables... [...] I think it is very clear. I can eat 2 during lunch and 2 during dinner, right? If I eat rice, I do not eat pasta, and if I eat pasta, I do not eat rice. And this cooked potato, how do you understand it? Is it potato or sweet potato?... I think it's potato. There is one and a half potato here. The small potato, I always eat two or even more. I already know what I shouldn't... [...] that I'm eating too much. Another thing, two tablespoons of cassava flour, is that too little or too much? What do you think? [...] It's on the average because white wheat flour has gum, right?

Leaf vegetables

[...] I think it is absurd to eat 15 leaves of lettuce, I'm going to eat lettuce during breakfast, lunch, and dinner?... I put about six leaves of lettuce, three or four leaves of chard, cut a tomato, na onion for dinner. [...] at lunch I eat everything, a little of everything.

Fruits

[...] I think one slice of pineapple is too little. [...] I eat almost a whole pineapple (laughs).Papaya is half a unit, that means half a unit is a segment, one section, right? Half!

Meats [...] Fish, I like mackerel better, since the flitch is solid, then I eat one. The omelet that I know is slightly bigger than Arab bread and you have to eat one and a half, it's too much!

Milk, cheese, and yogurt

I don't eat any of this: I do not eat yogurt or cheese or milk or anything because I don't like it too much. The 3 slices of mozzarella, I think it's too much because one for me is enough.

Oils and fats

This vegetable oil, I use every single day, but I do not use only a tablespoon, I use more, especially when I'm going to fry chicken, fish, then I use a lot. I also use a lot of butter, margarine, right... 
Table 1. Core Idea $(\mathrm{Cl})$ and discourse of the collective subject refering to serving sizes in cooking units from Unified Health Care System (SUS) patients with inadequate functional health literacy (Group 2). Fortaleza (CE), 2011.

\begin{tabular}{|c|c|}
\hline Core Idea & Discourse of the collective subject \\
\hline & Sugars and sweets \\
\hline & $\begin{array}{l}\text { One needs to know whether it's bee or sugarcane honey, right? Because there are two honeys, bee and } \\
\text { sugarcane, right?... I think two and a half tablespoons are ok, right? That small soup spoon. Do you } \\
\text { want honey as medicine or food? It's for food, it's to eat, right?... Then it's too little, only two small } \\
\text { tablespoons, two and a half tablespoons. }\end{array}$ \\
\hline $\mathrm{Cl} 4$ & Grains \\
\hline \multirow[t]{6}{*}{$\begin{array}{l}\text { Unfamiliar/uncommon } \\
\text { foods }\end{array}$} & $\begin{array}{l}\text { This breakfast cereal, what do you think it is? I don't know how to explain. There's no oat, right? But this } \\
\text { cereal is a bit bigger... It comes in a box too, right?... That you can also use with milk, you can add fruit, } \\
\text { however you want to consume it. Did you understand (laughs)... Well, more or less... }\end{array}$ \\
\hline & Non-starchy vegetables \\
\hline & $\begin{array}{l}\text { [...] we always use cooked pumpkin, right? Pumpkin, lettuce, beet, carrot, cucumber. I think that broccoli } \\
\text { and arugula are consumed by very few people here from our group... This arugula, judging from its } \\
\text { appearance, is a leaf vegetable, but I have never seen it... Further down it says } 15 \text { stems, so it must be a } \\
\text { leaf vegetable, like lettuce, or similar to lettuce... The best known vegetables are not listed, chard, kale, } \\
\text { and cabbage, the ones we always consume. } \\
\text { Fruits }\end{array}$ \\
\hline & $\begin{array}{l}\text { Which papaya is this? It even comes wrapped in a Styrofoam net, it is small, different from the common } \\
\text { papaya. The Hawaiian papaya is not wrapped, this one is wrapped. There is no common papaya, right? } \\
\text { I wonder why. I think the space here is too small (laughs), there are so many fruits that it didn't fit. I think } \\
\text { this papaya here is ideal for us to consume, that is why they did not put the other one. Oh! But it is } \\
\text { hidden here, now I found it, see?... The common papaya, right? It's to make salad, right? And persimmon? } \\
\text { It's a fruit that looks like tomato, its shape is that of a tomato, it's very good, it's red, very much like } \\
\text { tomato. And black plums, why do you think it is important? I don't know. It's to regulate bowel } \\
\text { movements... }\end{array}$ \\
\hline & Legumes \\
\hline & $\begin{array}{l}{[\ldots] \text { I would like to know what is this, cooked lentils. I know that cooked lentil is small grains but I never }} \\
\text { bought it to make. About dry peas, I don't know it, I know those that come in a can, the preserved } \\
\text { one... Dry peas and cooked soybeans, I have heard of them but have never eaten them... }\end{array}$ \\
\hline $\mathrm{Cl} 5$ & Meats \\
\hline \multirow[t]{2}{*}{ Small letters } & I am not familiar with this swordfish... \\
\hline & $\begin{array}{l}{[\ldots] \text { I asked myself.. my god, what is a serving size? It's good because here at the end they explain what }} \\
\text { a serving size is... The only reason it is not better is because the font is too tiny, too small... I am wearing } \\
\text { glasses, but it is still hard to see. I think it would be better for us if the font were bigger... }\end{array}$ \\
\hline
\end{tabular}

\section{DISCUSSION}

The high prevalence of insufficient and marginal literacy found by the present study, totaling $58.0 \%$ of the sample, has been mentioned in studies of American health services ${ }^{18}$, but in Brazil there is no information about such studies, except for that of CartheryGoulart et al. ${ }^{14}$ and two more specific studies for the area of mental health ${ }^{19,20}$. Carthery-Goulart et al. ${ }^{14}$ detected insufficient/marginal literacy in
$32.4 \%$ of their adult patients and $51.6 \%$ of their older patients. Since there were no older patients in the present study, the study percentages of inadequate $\mathrm{FHL}$ indicate that the present sample has worse FHL.

In the United States FHL has been concerning since the $1990 \mathrm{~s}^{4}$. Recent data show that there are about 90 million Americans with inadequate literacy ${ }^{18}$. Americans are more aware of the demographic and socioeconomic profiles of the FHL associated with different types of 
clientele seen at their health services ${ }^{21}$, and they also have studies on the economic impact of inadequate $\mathrm{FHL}^{22}$.

The discourses on GA serving sizes showed that both groups struggled to understand them. The participants' understanding of the number of servings recommended for each food or food group was limited. Group 1 manifests this in their discourse about grains and Group 2, about fruits. The participants understood that the recommended total number of servings should be consumed throughout the day, varying the available foods within a group, until the recommended number of servings is reached. However, it seems that the participants only came to understand the guide during the dialogue rounds, since the DCS associated with $\mathrm{CI} 2$ claims that the material cannot be understood from reading alone, and the participants also confuse the serving size of a given food and the recommended daily number of servings for each food group for that specific food. This becomes evident when an individual concludes that he should consume 24 tablespoons of rice a day because the serving size for rice is four tablespoons, and he should consume six servings of grains per day. In principle this is correct, but when different meals are considered, it would not make sense to consume the entire grain allowance in the form of rice.

Therefore, the way the foods are listed in the GA does not allow the user to understand that he may choose between different foods within a group to complete the daily number of servings for that group.

Despite the challenge to understand serving sizes and number of servings, some individuals in Group 2 noticed the excessive amounts of some food items, such as fifteen leaves of lettuce. In such cases, it is even harder to select serving size portions that are doable in order to reach the recommended daily intake.

Only individuals in Group 1 mentioned that serving sizes are confusing, both with respect to the standard adopted (cooking units) to define serving size (tablespoon, serving spoon, slice, three-fourths of a cup) and to the struggle to understand size when size refers to a steak or a ladle of beans half filled with bean broth, for example. It is not surprising that only Group 1 made such complaints because one of the important aspects of $\mathrm{FHL}$ is dealing with numbers, and numbers was the topic with the lowest scores. Carthery-Goulart et al. ${ }^{14}$ too found that numberrelated answers were more likely to be wrong. Group 2 members might not even have noticed the discrepancies mentioned by the other group.

Both groups were surprised with the omission of some common foods and inclusion of less common foods in their region, such as arugula, cucumber, persimmon, lentils, and dry peas. They noticed the absence of some common foods, such as cabbage, chard, kale, and the common papaya.

One core ideas was cited only by Group 2: the size of the letter used by the Guide, which the group considered too small. In fact, difficulty reading may be associated with low FHL.

Understanding and concepts of food and nutrition are periodically investigated, some of them using the same methods used herein, that is, the DCS ${ }^{23-25}$, but the population's understanding of the GA remains to be investigated.

Many countries have implemented food guides and assessed them, periodically updating them to the local culture, food availability, and the dietetic pattern of the population ${ }^{25}$. However, food guides have not specifically assessed their readers' understanding by FHL. The process of developing food guides is complex, so it is necessary to plan their development and health impact assessment ${ }^{13}$. In this perspective, it is critical to include the variable FHL in the process. Additionally, a recent study by Escott-Stump ${ }^{26}$ showed the need of approaching American food guidelines from the perspective of nutritional literacy, another theme that is yet unexplored in Brazil.

The present study identified the main obstacles to good GA understanding in light of readers' FHL. 
The study groups are patients seen at SUS, that is, the public health system that intends to ensure universal health access, equity, and complete care ${ }^{27}$. It is pertinent to focus on SUS patients because roughly $80 \%$ of the Brazilian population seeks preventive and therapeutic care therein. Most of these users are low income, although higher-income individuals also seek SUS care $^{28}$. However, the intended guarantees have obstacles. One of these obstacles recently pointed out is the population's low FHL, which prevents understanding of the available information.

The main limitations of the present study were, first, the impossibility of generalizing the findings because of the small number of interviewees. This is proper of the qualitative methodological approach of the DCS, which seeks the essence of social representations for the group represented by them ${ }^{16}$ here, the patients seen at SUS. The second limitation was the small number of people in the discussion rounds. When Bohm ${ }^{15}$ recommend using a very small number of participants in a dialogue round, his main concern was conducting the technique in companies because the participants know each other. When few people are in a dialogue round in companies, they may not feel comfortable expressing their true opinion on the issues being raised. This did not occur among the study participants because they did not know each other. Finally, the theme was discussed to exhaustion, that is, until the participants decided to end the session.

\section{O N CLUSION}

The difference between GA knowledge and understanding of the two groups of interviewees was very clear. This disparity included not knowing certain types of common foods, referred by individuals in the group with marginal and insufficient FHL.

Given what SUS proposes for its clientele regarding integral, equitable, and universal care, and of agreement with the study results, it would be interesting to know SUS' position regarding this heterogeneity. The different levels of understanding presented by individuals regarding GA understanding may represent a difficulty factor for NCD' prevention and treatment, responsible for much of SUS' spending.

The present study agrees with other studies that mention the importance of assessing the relationship between health-related educational actions, FHL, and adherence to the guidelines to improve health and prevent disease, especially to improve health-related educational material. In this sense it is very important to develop studies with SUS users regarding FHL and other themes discussed herein.

\section{ACKNOWLEDGMENTS}

We thank the Ministry of Health, the Conselho Nacional de Desenvolvimento Científico e Tecnológico, the Fundação Cearense de Apoio ao Desenvolvimento Científico e Tecnológico, and Ceará's State Department of Health.

\section{CONTRIBUTORS}

MAM COELHO helped to coordinate the study; tabulate and analyze the data; and write the manuscript. HAC SAMPAIO helped to conceive and coordinate the study, and write the manuscript. MPB PASSAMAI reviewed the bibliography, analyzed the data, and wrote the manuscript. LA CABRAL, TU PASSOS, and GP LIMA reviewed the bibliography, analyzed the data, and wrote the manuscript.

\section{REFERE NCES}

1. Brasil. Ministério da Saúde. Política nacional de promoção da saúde. Brasília: Ministério da Saúde; 2006.

2. Kumaresan J. Health literacy perspectives: Health literacy work of the World Health Organization. In: LM Hernadez, Rapporteur. Health literacy: Improving health, health systems, and health policy around the world: Workshop Summary. Washington (DC): Institute of Medicine of the National Academies; 2014 [cited 2014 Aug 6]. p.9-13. Available from <http://www.nap.edu/openbook. php?record_id=18325\&page=9>. 
3. Martínez-Hernáez A. Dialógica, etnografia e educação em saúde. Rev Saúde Pública. 2010; 44(3):399-405.

4. Baker DW. The meaning and the measure of health literacy. J Gen Intern Med. 2006; 21(8):878-83.

5. Grando KB. O letramento a partir de uma perspectiva teórica: origem do termo, conceituação e relações de escolarização. Seminário de Pesquisa em Educação da Região Sul, 2012 [acesso 2014 set 2]. Disponível em: <www.ucs.br/etc/ conferencias/index.php/anpedsul/9anpedsul/.../ 235>.

6. Kickbusch IS. Health literacy: Addressing the health and education divide. Health Promot Int. 2001; 16(Supl 3):289-97.

7. Institute of Medicine. Health literacy: A prescription to end confusion. Washington (DC): National Academic Press; 2004 [cited 2014 Aug 20]. Available from: <https://encrypted.google.com/ $\#$ hl=ptBR\&source $=h p \& q=$ Health + Literacy: $+A+$ Prescription+ to+End+Confusion+(2004)\&fp=63ea 79f9148c3561>.

8. Mellody M. Can earth's and society's systems meet the needs of 10 billion people? Summary of a Workshop. Division on Earth and Life Studies. Washington (DC): National Research Council; 2014.

9. Instituto Nacional de Estudos e Pesquisas Educacionais Anísio Teixeira. Programa Internacional de Avaliação de Estudantes (PISA): Relatório nacional Brasília: Inep; 2001 [acesso 2011 Jul 20]. Disponível em: <http://www.pisa.oecd.org/NatReports/ PISA2000/Brazilnatrep.pdf>.

10. Davis TC, Crouch MA, Long SW, Jackson RH, Bates P, George RB, et al. Rapid assessment of literacy levels of adult primary care patients. Fam Med. 1991; 23(Supl. 6):433-5.

11. Brasil. Ministério da Saúde. Guia alimentar: como ter uma alimentação saudável. Brasília: Ministério da Saúde; 2006.

12. Brasil. Ministério da Saúde. Guia alimentar para a população brasileira: promovendo a alimentação saudável. Brasília: Ministério da Saúde; 2005.

13. Barbosa RMS, Colares LGT, Soares EA. Desenvolvimento de guias alimentares em diversos países. Rev Nutr. 2008; 21(Supl. 4):455-67.

14. Carthery-Goulart MT, Anghinah R, Areza-Fegyveres R, Bahia VS, Brucki MO, Damin A, et al. Performance of a Brazilian population on the test of functional health literacy in adults. Rev Saúde Pública. 2009; 43(Suppl. 4):631-8.

15. Bohm D. On dialogue. New York: Taylor \& Francis e-Library; 2003.

16. Lefèvre $F$, Lefèvre AMC. O discurso do sujeito coletivo: um novo enfoque em pesquisa qualitativa. Caixias do Sul: Educs; 2003.
17. Lefèvre F, Lefèvre AMC. Qualiquantisoft. Universidade de São Paulo: Sales \& Paschoal. 2003 [acesso 2012 mar 23]. Disponível em: <http://www.spi-net. com.br/registro.asp>.

18. Chew LD. Self report measures of health literacy. In: Hernandez LM, Institute of Medicine. Roundtable on health literacy: Measures of health literacy: Workshop summary. Washington (DC): National Academies Press; 2009. pp.43-8.

19. Oliveira MO, Porto CS, Brucki SMD. S-TOFHLA in mild Alzheimer's disease and mild cognitive impairment patients as a measure of functional literacy. Dement Neuropsychol. 2009; 3(Suppl. 4):291-8.

20. Brucki SMD, Mansur LL, Carthery-Goulart MT, Nitrini R. Formal education, health literacy and MiniMental State Examination. Dement Neuropsychol. 2011; 5(Suppl. 1):26-30.

21. Clancy $C$. Health literacy measurement: Mapping the terrain. In: Hernandez LM, Institute of Medicine. Roundtable on health literacy: Measures of health literacy. Washington (DC): National Academies Press; 2009. pp.5-11.

22. Zarcadoolas C, Pleasant AF, Greer D. Advancing health Literacy: A framework for understanding and action. San Francisco (CA): Jossey-Bass Publishing; 2006.

23. Assao TY, Cervato-Mancuso AM. Alimentação saudável: percepções dos educadores de instituições infantis. Rev Bras Cresc Desenvol Hum. 2008; 18(Supl. 2):126-34.

24. Bandoni DH, Brasil BG, Jaime PC. Programa de alimentação do trabalhador: representações sociais de gestores locais. Rev Saúde Pública. 2006; 40(Supl. 5):837-42.

25. Assao TY, Cordeiro AA, Costa C, Cervato AM. Práticas e percepções acerca da segurança alimentar e nutricional entre os representantes das instituições integrantes de um centro de referência localizado na Região do Butantã, Município de São Paulo. Saúde e Soc. 2007; 16(Supl. 1):102-16.

26. Escott-Stump SA. Our nutrition literacy challenge: Making the 2010. Dietary guidelines relevant for consumers. J Am Diet Assoc. 2011; 111(Suppl. 7):979.

27. Brasil. Ministério da Saúde. Secretaria de Vigilância em Saúde. Saúde Brasil 2008: 20 anos de Sistema Único de Saúde (SUS). Brasília: Ministério da Saúde; 2009.

28. Organização Pan-Americana da Saúde. Indicadores básicos para a saúde no Brasil: conceitos e aplicações. $2^{a}$ ed. Brasília: Rede Interagencial de Informação para a Saúde; 2008.

Received on: 1/19/2013 Final version on: 9/17/2014

Approved on: 10/1/2014 
